\title{
Comparison of volatile and polyphenolic compounds in Brazilian green propolis and its botanical origin Baccharis dracunculifolia
}

\author{
Comparação de volatilidade e compostos polifenólicos na própolis verde \\ brasileira e sua origem botânica Baccharis dracunculifolia
}

\author{
Mário Roberto MARÓSTICA JUNIOR ${ }^{1}$, Andreas DAUGSCH ${ }^{1}$, Cleber Silveira MORAES ${ }^{1}$ \\ Carmen Lucia QUEIROGA², Gláucia Maria PASTORE ${ }^{1}$, Yong Kun PARK ${ }^{1 *}$
}

\begin{abstract}
Ethanolic extracts and essential oils from Green Propolis from southeastern Brazil and leaf buds from its botanical origin Baccharis dracunculifolia were analyzed by Reversed Phase High Performance Liquid Chromatography (RP-HPLC), Reversed Phase High Performance Thin Layer Chromatography (RP-HPTLC) and Gas Chromatography - Mass Spectrometry (GC-MS). The essential oils were obtained by hydro-distillation. Both ethanolic extracts and essential oils showed similar chromatographic profiles. Thirteen flavonoids were identified by RP-HPLC and RP-HPTLC analyses in both samples. Twenty-three volatile compounds were identified by GC-MS analyses. Seventeen were present in both essential oils. The major flavonoid compound in both extracts was artepillin C. The major volatile compound in both essential oils was nerolidol. The major compounds identified in this work could be used as chemical markers in order to classify and identify botanical origins of propolis.

Keywords: essential oil composition; Baccharis dracunculifolia; propolis; "Alecrim do campo"; flavonoids.
\end{abstract}

\section{Resumo}

Extratos etanólicos e óleos essenciais de própolis verde do sudeste brasileiro e gemas de sua origem botânica (Baccharis dracunculifolia) foram analisados por CLAE-FR (Cromatografia Líquida de Alta Eficiência em Fase Reversa), CCDAE (Cromatografia em Camada Delgada de Alta Eficiência) e CG-EM (Cromatografia Gasosa acoplada a Espectrometria de Massas). Os óleos essenciais foram obtidos por hidro destilação. Extratos etanólicos e óleos essenciais de Baccharis dracunculifolia e de própolis mostraram perfis cromatográficos similares entre si. Treze flavonóides foram identificados por CLAE-FR e CCDAE em ambas as amostras. Vinte e três compostos voláteis foram identificados por CG-EM, sendo dezessete deles presentes em ambos os óleos essenciais. Artepillin C foi o flavonóide encontrado em maiores concentrações em ambas as amostras, enquanto nerolidol foi o volátil majoritário em ambos os óleos essenciais. Os compostos majoritários identificados neste trabalho podem ser utilizados como marcadores químicos para classificar de forma prática e identificar origens botânicas de própolis.

Palavras-chave: composição de óleos essenciais; Baccharis dracunculifolia; própolis; Alecrim do campo; flavonóides.

\section{Introduction}

Propolis (also referred to as bee's glue) possesses a broad spectrum of biological activities, such as anti-hepatotoxic, antitumor, antiviral, antioxidant, antimicrobial and antiinflammatory properties, and is therefore used as a constituent of health foods and functional foods (BURDOCK, 1998).

Propolis is collected from the leaf buds of numerous tree species (alder, birch, palm, pine, poplar and willow). Other plant exudates and secretions, such as substances secreted by plants to seal wounds, lipophylic substances on leaves, mucilages, gums, resins, lattices, etc. are also used (BANKOVA; CASTRO; MARCUCCI, 2000). Brazilian Green Propolis is collected from the tender sprouts of Baccharis dracunculifolia, which is commonly found in the States of Minas Gerais, São Paulo, Rio de Janeiro and Paraná (ALENCAR et al., 2005; PARK; ALENCAR;
AGUIAR, 2002; PARK; IKEGAKI; ALENCAR, 2000). In Brazil, twelve distinct groups of propolis have been classified according to their botanical origin and biological properties. Brazilian Green Propolis is classified as Group 12, which is the most commercialized and largely used in foods and beverages to improve health and prevent diseases (PARK et al., 2005).

Propolis is in general composed of $50 \%$ resin and balsam, $30 \%$ wax, $10 \%$ essential and aromatic oils, $5 \%$ pollen, and $5 \%$ other substances, such as aliphatic acids, esters, aromatic acids, fatty acids, carbohydrates, aldehydes, amino acids, ketones, chalcones, dihydrochalcones, terpenoids, vitamins (B1, B2, B6, C and E) and minerals (aluminum, antimony, calcium, cesium, copper, iron, lanthanum, manganese, mercury, nickel, silver, vanadium and zinc) (ALMEIDA; MENEZES, 2002).

\footnotetext{
Recebido para publicação em 14/11/2006

Aceito para publicação em 19/10/2007 (002061)

Departamento de Ciências de Alimentos, Faculdade de Engenharia de Alimentos - FEA, Universidade Estadual de Campinas - UNICAMP,

Barão Geraldo, CP 6177, CEP 13081-970, Campinas - SP, Brasil, E-mail: ykpark@fea.unicamp.br

${ }^{2}$ Centro Pluridisciplinar de Pesquisas Químicas e Biológicas - CPQBA, Universidade Estadual de Campinas - UNICAMP,

Barão Geraldo, CP 617, CEP 13083-970, Campinas - SP, Brasil

${ }^{*}$ A quem a correspondência deve ser enviada
} 
The health benefits of propolis are related to its content of flavonoids and other phenolic compounds (BANKOVA; CASTRO; MARCUCCI, 2000). As volatile components, various mono- and sesquiterpenes are found (BANKOVA et al., 1994, FERRACINI et al., 1995).

\section{Materials and methods}

\subsection{Propolis and its botanical origin}

Brazilian Green Propolis, produced by africanized Apis mellifera, and B. dracunculifolia leaf buds were collected in southeastern Brazil and immediately analyzed.

\subsection{Distillation}

The essential oil of $B$. dracunculifolia leaves was extracted by hydrodistillation and collected in a bottom with methylene chloride. After $1 \mathrm{~h}$ of distillation, the oil was separated in a funnel. The aqueous portion was extracted twice with methylene chloride. The organic phases were dried with anhydrous sodium sulfate, filtered and dried under vacuum. The same procedure was performed with the propolis.

\subsection{GC-MS analyses}

Were carried out in a GC 6890N Agilent gas chromatograph with a 5975 mass spectrometry detector equipped with a HP5MS column ( $30 \mathrm{~m} \times 0.25 \mathrm{~mm} \times 0.25 \mu \mathrm{m})$. Column temperature was programmed as follows (QUEIROGA; FUKAI; MARSAIOLI, 1990): 55 to $120^{\circ} \mathrm{C}$ at $20^{\circ} \mathrm{C} / \mathrm{min}, 120$ to $150{ }^{\circ} \mathrm{C}$ at $1.5^{\circ} \mathrm{C} / \mathrm{min}$, 150 to $250^{\circ} \mathrm{C}$ at $20^{\circ} \mathrm{C} / \mathrm{min}, 250^{\circ} \mathrm{C}(10$ minutes $)$. Carrier gas was helium $(1 \mathrm{~mL} / \mathrm{min})$. Injector and detector temperatures were 220 and $250^{\circ} \mathrm{C}$, respectively. The identification of the compounds was based on retention indices relative to $\mathrm{C} 9-\mathrm{C} 20 \mathrm{n}$-alkane series (ADAMS, 1995), by computer search using the NIST107 library, and by comparison with the spectra data in the literature.

\subsection{Preparation of propolis and B. dracunculifolia leaf bud ethanolic extracts}

The ethanolic extracts were prepared as previously described (PARK et al., 2005). Two grams of propolis and $25 \mathrm{~mL}$ of $80 \%$ $(\mathrm{v} / \mathrm{v})$ ethanol were used for extraction at $70{ }^{\circ} \mathrm{C}$ for 30 minutes. After extraction, the mixture was centrifuged at 10,000 $\mathrm{x}$ g and the resulting supernatant was evaporated to dryness at $40^{\circ} \mathrm{C}$ and vacuum. The leaf buds were removed with a knife without breaking them into pieces, and two grams of the samples were rinsed immediately with $50 \mathrm{~mL}$ of $80 \%$ ethanol, at $70{ }^{\circ} \mathrm{C}$, for 1 hour, to remove superficial resins and then centrifuged. The supernatant was evaporated to dryness at $40^{\circ} \mathrm{C}$ and vacuum. The dried propolis and Baccharis dracunculifolia leaf bud resin extracts were dissolved in methanol and used for RP-HPLC and RP-HPTLC analyses.

\subsection{Reversed-phase high-performance liquid chromatography (RP-HPLC)}

The analyses of the chemical compounds in propolis and leaf bud extracts were performed by RP-HPLC, with a liquid chromatograph equipped with a YCM Pack ODS-A column and photodiode array detector (SPD-M10-A, Shimadzu Co., Kyoto, Japan). The mobile phase was acetic acid:methanol:water (5:75:60 by vol). The flow rate was $1 \mathrm{~mL} / \mathrm{min}$. For quantification, a DAD trace of $254 \mathrm{~nm}$ was used. The identification of the flavonoids was carried out through retention times and co-chromatography with authentic standard substances (Extrasynthese Co., Genay Cedex, France).

\subsection{Reversed-phase high-performance thin layer chromatography (RP-HPTLC).}

Precoated RP-18 $\mathrm{F}_{254} \mathrm{~S}$ silica gel plates (Merck Co., Darmstadt, Germany) were used. Six microliters of the ethanolic extracts were applied, and an ascending chromatographic run with a mobile phase of ethanol:water (55:45 vol/vol) was performed during 1.5 hour. The detection of flavonoids was carried out by UV radiation at $366 \mathrm{~nm}$ (PARK et al., 2004).

\section{Results and discussion}

As shown in Figures 1 and 2, ethanolic extracts of G12 propolis and its botanical origin $B$. dracunculifolia show a similar chromatographic profile. The thirteen flavonoids identified in

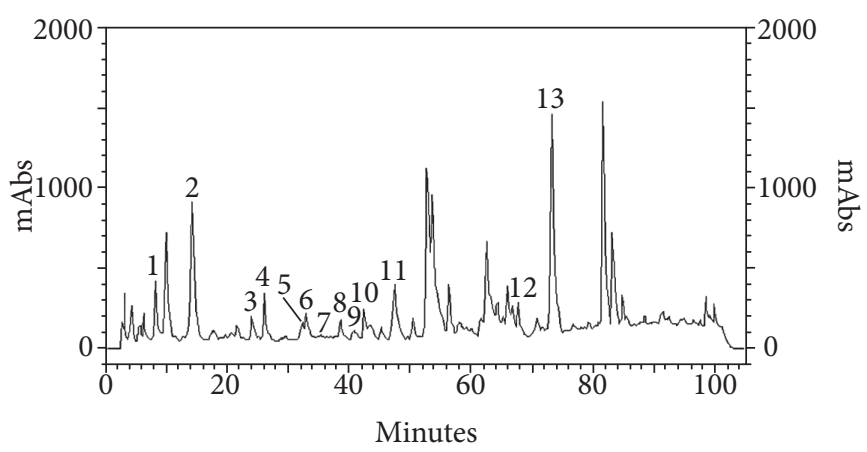

Figure 1. RP-HPLC of G12 propolis ethanolic extracts: 1 = Coumaric acid; 2 = Rutin; 3 = Pinobanksin; $4=$ Quercetin; 5 = Kaempferol; 6 =Apigenin; 7 = Pinocembrin; 8 = Pinobanksin-3-acetate; 9 = Chrysin; $10=$ Galangin; $11=$ Kaempferide; $12=$ Tectochrysin; and $13=$ Artepillin C.

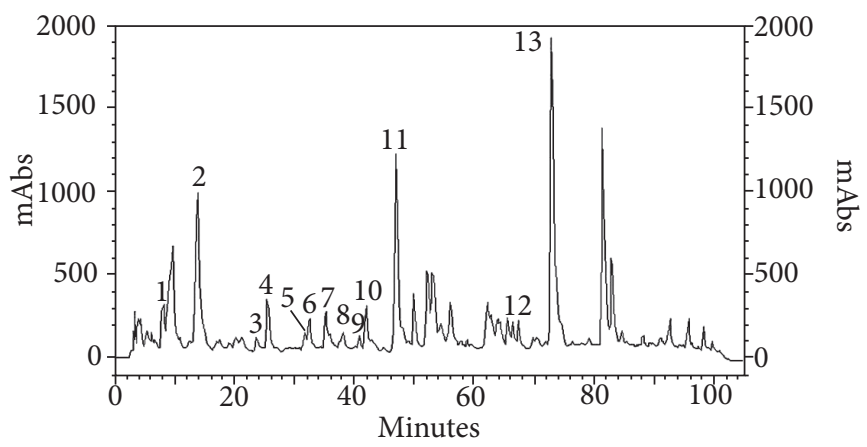

Figure 2. RP-HPLC of Baccharis dracunculifolia ethanolic extracts: 1 = Coumaric acid; 2 = Rutin; 3 = Pinobanksin; $4=$ Quercetin; 5 = Kaempferol; 6 = Apigenin; 7 = Pinocembrin; 8 = Pinobanksin-3-acetate; 9 = Chrysin; $10=$ Galangin; $11=$ Kaempferide; 12 = Tectochrysin; and $13=$ Artepillin C. 
G12 propolis were also present in the ethanolic extracts of $B$. dracunculifolia leaf buds, although in different relative amounts (Table 1). The major compound in both extracts was artepillin C. The relative amounts of flavonoids in the ethanolic extracts of B. dracunculifolia leaf buds are higher than in the extracts of G12 propolis. This is due to the fact that propolis contains about $30 \%$ wax, $10 \%$ essential and aromatic oils, $5 \%$ pollen and $5 \%$ other substances, and only about $50 \%$ resins of $B$. dracunculifolia. In addition to the comparison of the flavonoid profile, we also compared the volatile composition of G12 propolis and its botanical origin.

The GC analyses of $B$. dracunculifolia and propolis essential oils revealed a great similarity between them, as shown in Figures 3 and 4. Twenty-three compounds were identified. Seventeen were present in both oils. The relative amount of each compound was different between the oils. Several components were present in trace amounts in both samples, such as betapinene, benzeneethanol, 4-terpineol and alpha-humulene. The components present in concentrations higher than $1 \%$ in both oils were: alpha-pinene, 1-phenyl-ethanone, linalool, transcaryophyllene, delta-cadinene, nerolidol, spathulenol and globulol. The components contribute to more than $40 \%$ of the total oil for both samples, as shown in Table 2. The compound present in the highest concentration in both of the oils was nerolidol: $14.82 \%$ in B. dracunculifolia essential oil and 6.64\% in Green Propolis oil. Excepting epi-alpha-cadinol, all the major compounds ( $>1 \%$ ) present in B. dracunculifolia were also present in the propolis oil.

According to a previous study (FERRACINI et al., 1995), alpha-pinene, beta-pinene, limonene, alpha-terpineol, transcaryophyllene, aromadendrene, alpha-humulene, deltacadinene, nerolidol, spathulenol and globulol were identified in B. dracunculifolia essential oil (female and male plant). Our results confirm the presence of these 11 compounds in B. dracunculifolia, as well as in G12 propolis. Additionally, we identified benzeneacethaldehyde, 1-phenyl-ethanone, linalool, benzeneethanol, benzeneacetonitrile and 4-terpineol in both essential oils. 1-Phenyl-ethanone and linalool were the major compounds in both essential oils. The remaining compounds were found only in minor quantities. Myrcene, benzenepropanoic acid methyl ester and ethyl 3-phenylpropionate were found in G12 propolis essential oil, but were not present in $B$. dracunfulifolia oil. This might have been caused by the action of africanized Apis mellifera, adding other materials during the production of propolis. Gamma-muurolene, cis-beta-guaiene and epi-alpha-cadinol (torreyol) were found in B. dracunculifolia but not in G12 propolis.

\section{Conclusion}

We reported the identification of 11 major volatile compounds and 13 flavonoids in G12 propolis and B. dracunculifolia. The major compounds identified in this work could be used as

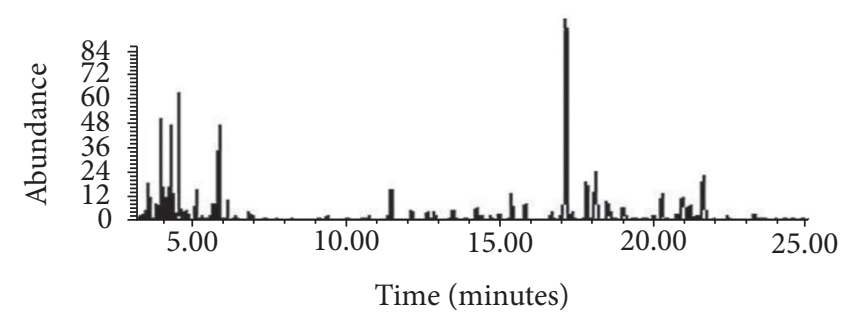

Figure 3. Chromatographic profile of Baccharis dracunculifolia essential oil obtained by GC-MS.

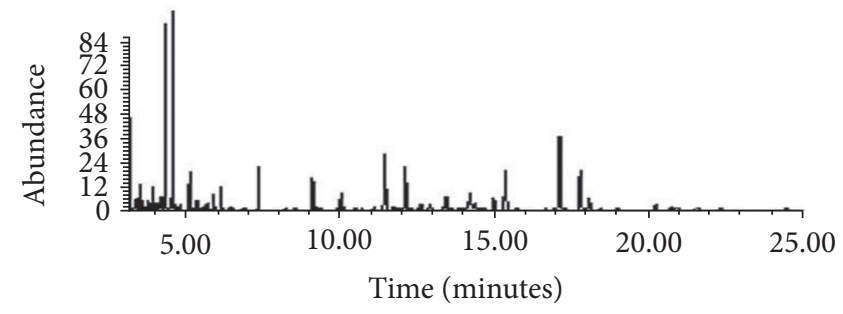

Figure 4. Chromatographic profile of the volatile portion of G12 propolis essential oil obtained by GC-MS.

Table 1. Flavonoid composition of G12 propolis and Baccharis dracunculifolia.

\begin{tabular}{|c|c|c|c|c|c|c|c|}
\hline \multirow[t]{2}{*}{$\#$} & \multirow[t]{2}{*}{ Name } & \multicolumn{3}{|c|}{ Baccharis dracunculifolia } & \multicolumn{3}{|c|}{ G12 propolis } \\
\hline & & $\begin{array}{c}\text { Retention time } \\
\text { (minutes) }\end{array}$ & $\begin{array}{c}\text { Area } \\
(\mathrm{mAU})\end{array}$ & $\begin{array}{c}\text { Content } \\
\text { (mg.g }{ }^{-1} \text { dry extract) }\end{array}$ & $\begin{array}{c}\text { Retention time } \\
\text { (minutes) }\end{array}$ & $\begin{array}{c}\text { Area } \\
(\mathrm{mAU})\end{array}$ & $\begin{array}{c}\text { Content } \\
\left.\text { (mg.g }{ }^{-1} \text { propolis }\right)\end{array}$ \\
\hline 1 & Coumaric acid & 8.165 & 9332459 & 2.49 & 8.324 & 8744338 & 2.33 \\
\hline 2 & Rutin & 13.972 & 67294468 & 24.49 & 14.320 & 47908775 & 17.44 \\
\hline 3 & Pinobanksin & 23.672 & 7210896 & 7.19 & 24.034 & 8470280 & 8.45 \\
\hline 4 & Quercetin & 25.556 & 15028197 & 3.78 & 25.978 & 11944283 & 3.00 \\
\hline 5 & Kaempferol & 31.926 & 6219622 & 0.91 & 32.397 & 6444702 & 0.94 \\
\hline 6 & Apigenin & 32.638 & 13752477 & 2.51 & 33.072 & 13525546 & 2.47 \\
\hline 7 & Pinocembrin & 35.329 & 9704040 & 27.07 & 36.417 & 2802988 & 7.82 \\
\hline 8 & Pinobanksin-3-acetate & 38.170 & 9771622 & 6.59 & 38.614 & 11535066 & 7.78 \\
\hline 9 & Chrysin & 40.915 & 6093583 & 1.13 & 41.277 & 3498328 & 0.65 \\
\hline 10 & Galangin & 41.987 & 12318031 & 2.30 & 42.480 & 9369716 & 1.75 \\
\hline 11 & Kaempferide & 46.974 & 49555936 & 7.11 & 47.413 & 25225045 & 3.62 \\
\hline 12 & Tectochrysin & 67.394 & 13244539 & 2.93 & 67.725 & 14505198 & 3.21 \\
\hline 13 & Artepillin C & 72.899 & 92100059 & 56.09 & 73.183 & 59455291 & 36.21 \\
\hline
\end{tabular}


Table 2. Volatile composition of G12 propolis and Baccharis dracunculifolia essential oils.

\begin{tabular}{|c|c|c|c|c|c|c|c|}
\hline \multirow[t]{2}{*}{ Constituents } & \multirow[t]{2}{*}{ MW } & \multirow[t]{2}{*}{ R.I. } & \multirow[t]{2}{*}{ R.I. lit. } & \multicolumn{2}{|c|}{ B. dracunculifolia } & \multicolumn{2}{|c|}{ G12 propolis } \\
\hline & & & & $t_{\mathrm{r}}($ minutes $)$ & Area (\%) & $\operatorname{tr}$ (minutes) & Area (\%) \\
\hline Alpha-pinene & 136 & 930 & 932 & 3.20 & 1.56 & 3.20 & 1.59 \\
\hline Beta-pinene & 136 & 983 & 980 & 3.53 & 0.64 & 3.53 & 0.63 \\
\hline Myrcene & 136 & 990 & 991 & - & - & 3.57 & 0.14 \\
\hline Limonene & 136 & 1036 & 1031 & 3.93 & 2.17 & 3.93 & 0.72 \\
\hline Benzeneacethaldehyde & 120 & 1047 & - & 4.06 & 0.97 & 4.05 & 0.30 \\
\hline Ethanone, 1-phenyl- & 122 & 1071 & - & 4.30 & 1.92 & 4.30 & 4.85 \\
\hline Linalool & 154 & 1102 & 1098 & 4.57 & 2.82 & 4.57 & 4.99 \\
\hline Benzeneethanol & 122 & 1115 & - & 4.79 & 0.18 & 4.79 & 0.24 \\
\hline Benzeneacetonitrile & 117 & 1135 & - & 5.10 & 0.75 & 5.10 & 1.19 \\
\hline 4-terpineol & 154 & 1170 & 1177 & 5.68 & 0.43 & 5.68 & 0.23 \\
\hline Alpha-terpineol & 154 & 1181 & 1189 & 5.85 & 2.55 & 5.86 & 0.51 \\
\hline Unknown & 120 & 1198 & - & 6.13 & 0.65 & - & - \\
\hline Unknown & 154 & 1242 & - & 6.84 & 0.28 & - & - \\
\hline Benzenepropanoic acid, methyl ester & 164 & 1274 & - & - & - & 7.35 & 1.94 \\
\hline Ethyl 3-phenylpropionate & 178 & 1349 & 1350 & - & - & 9.11 & 1.72 \\
\hline Unknown & 204 & 1382 & - & - & - & 10.02 & 0.97 \\
\hline Trans-caryophyllene & 204 & 1414 & 1418 & 11.44 & 1.76 & 11.45 & 4.05 \\
\hline Aromadendrene & 204 & 1442 & 1439 & 12.11 & 0.48 & 12.11 & 3.13 \\
\hline Alpha-humulene & 204 & 1457 & 1454 & 12.63 & 0.40 & 12.64 & 0.48 \\
\hline Gamma-muurolene & 204 & 1478 & 1477 & 13.45 & 0.77 & - & - \\
\hline Cis-beta-guaiene & 204 & 1488 & 1490 & 14.22 & 0.77 & - & - \\
\hline Delta-cadinene & 204 & 1524 & 1524 & 15.36 & 1.70 & 15.36 & 3.37 \\
\hline Nerolidol & 222 & 1564 & 1564 & 17.13 & 14.82 & 17.12 & 6.64 \\
\hline Spathulenol & 220 & 1577 & 1576 & 17.80 & 2.85 & 17.80 & 3.57 \\
\hline Globulol & 222 & 1583 & 1583 & 18.06 & 4.21 & 18.08 & 1.25 \\
\hline Epi-alpha-cadinol (torreyol) & 222 & 1640 & 1640 & 20.93 & 1.66 & - & - \\
\hline
\end{tabular}

MW = Molecular Weight; R.I. = Retention Index relative to n-alkanes; R.I. lit. = Retention Index as found in literature (ADAMS, 1995); and $t_{\mathrm{r}}=$ retention time, in minutes.

chemical markers in order to classify and identify botanical origins of propolis. Further research in this area could focus on the evaluation of the biological activity of the compounds described in this investigation.

\section{Acknowledgements}

The authors would like to thank CNPq (Conselho Nacional de Desenvolvimento Científico e Tecnológico, Brazil) for its support.

\section{References}

ADAMS, R. P. Identification of essential oil components by gas chromatography/ mass spectrometry. 4 ed. Allued Publ. Corp., Illinois, USA, 1995.

ALENCAR, S. M. et al. Composição química de Baccharis dracunculifolia, fonte botânica das própolis dos estados de São Paulo e Minas Gerais. Ciência Rural, Santa Maria, Brazil, v. 35, n. 4, p. 909-915, 2005.

ALMEIDA, E. C.; MENEZES, H. Anti-inflammatory activity of propolis extracts: a review. J. Venom. Anim. Toxins, Botucatu, v. 8, n. 2, p. 191-212, 2002.

BANKOVA, V.; CASTRO, S. L. D.; MARCUCCI, M. C. Propolis: recent advances in chemistry and plant origin. Apidologie, Les Ulis Cedex A, France, v. 31, p. 3-15, 2000.
BANKOVA, V. et al.Volatile constituents of propolis. Z. Naturforsch. Tubingen, Germany, v. 49c, p. 6-10, 1994.

BURDOCK, G. A. Review of the Biological Properties and Toxicity of Bee Propolis (Propolis). Food Chem. Toxicol., Virginia, USA, v. 36, n. 4, p. 347-363, 1998.

FERRACINI, V. L. et al. Essential Oils of Seven Brazilian Baccharis Species. J. Essent. Oil Res., Illinois, USA, v. 7, n. 4, p. 355-367, 1995.

PARK, Y. K.; ALENCAR, S. M.; AGUIAR, C. L. Botanical origin and chemical composition of Brazilian propolis. J. Agric. Food Chem., California, USA, v. 50, n. 9, p. 2502-2506, 2002.

PARK, Y. K.; et al. Suppressive Effects of Ethanolic Extracts from Propolis and Its Main Botanical Origin on Dioxin Toxicity. J. Agric. Food Chem., California, USA, v. 53, n. 26, p. 10306-10309, 2005.

PARK, Y. K.; Ikegaki, M.; Alencar, S. M. Evaluation of brazilian propolis by both physicochemical methods and biological activity. Honeybee Science, Tamagawa, Japan, v. 21, p. 85-90, 2000.

Park, Y. K. et al. Chemical Constituents in Baccharis dracunculifolia as the Main Botanical Origin of Southeastern Brazilian Propolis. J. Agric. Food Chem., California, USA, v. 52, n. 5, p. 1100-1103, 2004.

QUEIROGA, C. L.; FUKAI, A.; MARSAIOLI, A. J. Composition of the Essential Oil of Vassoura. J. Bras. Chem. Soc., São Paulo, Brazil, v. 1, n. 3, p. 105-109, 1990. 